\title{
Effects of a bovine colostrum-supplemented diet on some gut parameters in weaned piglets ${ }^{*}, * *$
}

\author{
Antoine HugueT, Bernard SÈve, Jean LE DividicH, \\ Isabelle LE HUËROU-LURON*** \\ Unité Mixte de Recherches, Systèmes d'Élevage, Nutrition Animale et Humaine, \\ INRA, Domaine de la Prise, 35590 St-Gilles, France
}

(Received 4 October 2005; accepted 22 November 2005)

\begin{abstract}
The present study investigated the effects of a bovine colostrum-supplemented diet on gut post-weaning adaptation and health in piglets. Thirty-six 21-d-old piglets were allocated to one of the three following dietary treatments: sow-reared (SR), weaned on a control starter diet (WCtrl) or on a starter diet supplemented with bovine colostrum (WCol) until slaughter at $28 \mathrm{~d}$ or $35 \mathrm{~d}$ of age. Gastric $\mathrm{pH}$ and intestinal bacteriological, structural and functional parameters were determined. Compared to WCtrl, the gastric $\mathrm{pH}$ was lower $(P<0.05)$ and the duodenal lactobacilli:coliform ratio was higher $(P=0.05)$ in WCol piglets. The relative small intestine weight was $18 \%(P<0.05)$ higher in WCol piglets than in SR piglets. Duodenal villous height was lower $(P<0.01)$ in WCtrl than in SR piglets, whereas the value for WCol piglets was intermediate. The weaning-increased crypt cell proliferation was not affected by bovine colostrum supplementation. The mucosal ribosomal capacity was higher $(P<0.05)$ in $\mathrm{W}$ than in SR piglets. In conclusion, a diet supplemented with colostrum induced, although not always significantly, variations of gut parameters, suggesting that globally, colostrum may limit weaning-induced gut structural and microbial alterations. The observed effects occurred early and were maintained throughout the post-weaning adaptive phase.
\end{abstract}

bovine colostrum / intestine / microflora / mucosa growth / weaning

\section{INTRODUCTION}

From a nutritional aspect, weaning of piglets is characterised by a temporary anorexia inducing a growth check that is associated with a decline of sanitary status. The ban within the European Union of growth promoting antibiotic-supplemented diets in livestock production requires finding alternative issues. One alternative is the

\footnotetext{
* Supported by the French project "Porcherie verte".

** Presented in part at the 1st congress of the French Society of Nutrition, November 17-19, 2003, Clermont-Ferrand, France [Huguet A, Perrier C, Favier C, Le Dividich J, Le Huërou-Luron I (2004). Supplementation of a weaning diet with bovine colostrum improves health of the small intestine of weaned piglets (abstract). Reprod Nutr Dev 44: 148-149], and at the 12th International Conference on Production Diseases in Farm Animals, East Lansing, Michigan, USA [Le Huërou-Luron I, Huguet A, Le Dividich J (2004). Bovine colostrum as an alternative to feed additive in weaning diet improves gut health of piglets. In: Proceedings of 12th International Conference on Production Diseases in Farm Animals (Joshi NP, Herdt TH, Eds.), East Lansing, Michigan, USA].

*** Corresponding author: Isabelle.Luron@ rennes.inra.fr
} 
supplementation of the weaning diet with natural substances. However, large discrepancies in the reported results exist.

Bovine colostrum is a commercially available co-product of the dairy industry. Bovine colostrum-supplemented starter diet improves the growth performance and sanitary status of piglets during the early postweaning period $[1,2]$. These beneficial effects could be explained by both an observed increase in feed intake level as early as the first days after weaning [1] and a likely direct effect on gut health. Giving bovine colostrum orally prevents chemically-induced villous atrophy in mice [3] and stimulates mucosal healing of patients suffering from inflammatory gut disease [4]. It reduces diarrhoeal symptoms in infants [5] and protects intestinal mucosa from pathogen bacteria adhesion [6].

Altogether, these studies suggest that bovine colostrum could be an alternative to growth promoting antibiotics in order to prevent weaning-induced gut disorders. The aim of our study was to understand how bovine colostrum interacts with the porcine gut at weaning. Therefore, the effects of a bovine colostrum-supplemented diet on the structure and digestive functions of the intestinal mucosa, as well as on the composition of luminal microflora of piglets during the first two post-weaning weeks were investigated.

\section{MATERIALS AND METHODS}

\subsection{Animals and dietary treatments}

The experiments were conducted under the guidelines of the French Ministry of Agriculture for animal research. Thirty-six crossbred Pietrain $\times$ (Large White $\times$ Landrace) $21 \mathrm{~d}$-old piglets from the experimental herd of INRA (Saint-Gilles) were allocated into 12 littermate triplets on the basis of BW. Within each triplet, piglets were randomly allocated to one of the following three dietary treatments: sow-reared (SR), weaned on a control starter diet (WCtrl) or on a starter diet supplemented with freeze-dried defatted bovine colostrum at the rate of $5 \%$ of dry matter (DM) (WCol). After weaning of WCtrl and WCol piglets, the remaining piglets of littermates were adjusted to 10 piglets with additional non-experimental piglets. Six littermate triplets were slaughtered at $28 \mathrm{~d}$ of age, and the 6 other littermate triplets were slaughtered at $35 \mathrm{~d}$ of age. No creep feed was provided during the suckling period. At $21 \mathrm{~d}$ of age, a catheter was surgically implanted into a jugular vein of piglets after 2-h fasting. The catheter was introduced in a bag placed on the dorsal side of the piglet's neck and fixed with a surgical tape. Sow-reared piglets were returned to their mothers after a 3-h recovery, whereas weaned (W) piglets were individually housed in stainless steel metabolic cages providing visual contact with each other. Room temperature was initially set at $32{ }^{\circ} \mathrm{C}$, progressively decreased to $28^{\circ} \mathrm{C}$ on $\mathrm{d} 7$ post-weaning and was maintained constant thereafter.

In the present study, sow-reared piglets were considered as a reference of piglets with undisturbed digestive functions compared to piglets that had to face weaninginduced dietary changes. Weaned piglets were fed a complete formula based on cereals, soybean meal, maltodextrin, dairy products, fish meal and vegetal oil (Tab. I). Bovine colostrum was individually collected from the first three milkings of healthy cows from the experimental herd of INRA (Méjussaume) and frozen at $-20^{\circ} \mathrm{C}$. After thawing, pooled bovine colostrum was defatted using a dairy separator and freeze-dried. Total protein content of the freeze-dried bovine colostrum was $550 \mathrm{mg} \cdot \mathrm{g}^{-1} \mathrm{DM}$, IgG representing $41 \%$ of total protein. The various growth factors present in the freezedried bovine colostrum were incompletely defined but included insulin $\left(368 \mathrm{ng} \cdot \mathrm{g}^{-1}\right.$ DM), IGF-I (1.61 $\left.\mu \mathrm{g} \cdot \mathrm{g}^{-1} \mathrm{DM}\right)$, and transforming growth factor $\beta$ (670 $\left.\mathrm{ng} \cdot \mathrm{g}^{-1} \mathrm{DM}\right)$. The two starter diets were formulated to meet $\mathrm{W}$ piglet requirements [7] and were similar in net energy content (19 and $18.8 \mathrm{MJ} \cdot \mathrm{kg}^{-1} \mathrm{DM}$ for WCtrl and WCol diets, respectively). The WCtrl diet was 
Table I. Composition of the diets given to weaned piglets.

\begin{tabular}{|c|c|c|}
\hline & \multicolumn{2}{|c|}{ Diet } \\
\hline & $\mathrm{WCtrl}^{1}$ & $\mathrm{WCol}^{2}$ \\
\hline & \multicolumn{2}{|c|}{$\mathrm{g} \cdot \mathrm{kg}^{-1}$ air-dried diet } \\
\hline \multicolumn{3}{|l|}{ Ingredients } \\
\hline Wheat seeds, ground & 246.6 & 246.6 \\
\hline Barley seeds, ground & 247 & 247 \\
\hline Soybean meal & 160 & 160 \\
\hline Maltodextrins & 42 & 52 \\
\hline Dehydrated whey & 150 & 90 \\
\hline $\begin{array}{l}\text { Freeze-dried defatted } \\
\text { bovine colostrum }\end{array}$ & - & 50 \\
\hline $\begin{array}{l}\text { Soluble fish protein } \\
\text { concentrate }\end{array}$ & 82.5 & 82.5 \\
\hline Sunflower oil & 28 & 28 \\
\hline $\begin{array}{l}\text { Trace element and vitamin } \\
\text { premix }^{3}\end{array}$ & 5 & 5 \\
\hline $\mathrm{CaCO}_{3}$ & 15.2 & 15.2 \\
\hline $\mathrm{CaHPO}_{4} \cdot 2 \mathrm{H}_{2} \mathrm{O}$ & 20 & 20 \\
\hline L-lysine- $\mathrm{HCl}$ & 1.25 & 1.25 \\
\hline DL-methionine & 0.85 & 0.85 \\
\hline L-threonine & 1.3 & 1.3 \\
\hline \multirow[t]{2}{*}{ L-tryptophan } & 0.3 & 0.3 \\
\hline & \multicolumn{2}{|c|}{$\mathrm{MJ} \cdot \mathrm{kg}^{-1}$ dry matter } \\
\hline Crude energy & 19 & 18.8 \\
\hline
\end{tabular}

${ }^{1}$ WCtrl, control starter diet.

${ }^{2}$ WCol, bovine colostrum-supplemented starter diet.

${ }^{3}$ Contains the following amount of vitamins and minerals in $\mathrm{g} \cdot \mathrm{kg}^{-1}$ of diet: calcium carbonate (excipient) 550.69 ; zinc oxide (78\% Zn) 25.7; copper sulphate $(25 \% \mathrm{Cu}) 16.0$; manganese oxide $(62 \% \mathrm{Mn})$ 11.7 ; iron carbonate $(40 \% \mathrm{Fe}) 50.0$; calcium iodate (62\% I) 0.32 ; cobalt sulphate $(21 \%$ Co) 1.9 ; sodium selenite $(1 \% \mathrm{Se}) 6.0$; retinol $\left(500,000 \mathrm{IU} \cdot \mathrm{g}^{-1}\right) 4.8$; vitamin A/vitamin D-3 (500,000/100,000 IU.g $\left.{ }^{-1}\right)$

1.2; cholecalciferol $\left(500,000 \mathrm{IU} \cdot \mathrm{g}^{-1}\right)$ 0.96; tocopherol (500 IU.g ${ }^{-1}$ ) 16.0; menadione (22.7\%) 1.76; thiamin $(98 \%)$ 0.4; riboflavin $(80 \%) 2.5$; niacin (pure) 6.0; Ca pantothenate (99\%) 3.0; pyridoxine (pure) 2.0; biotin (2\%) 2.0; folic acid (pure) 0.4; cyanocobalamin $(0.1 \%)$ 10.0; ascorbic acid (pure) 20.0; choline chloride (60\%) 266.67.

free of any growth promoting additive. The WCol diet contained solely freeze-dried bovine colostrum in replacement of dehydrated whey and maltodextrin. Weaned piglets were fed twice a day (at 0900 and $1700 \mathrm{~h}$ ) and had free access to water. The actual feed intake level was measured by weighing the feeding trough before and after meals. Weaned piglets were pair-fed until the end of the experimental period. More precisely, the WCtrl diet was offered for $60 \mathrm{~min}$ to the WCtrl piglets. Then WCol piglets were offered the same amount of feed intake level as WCtrl piglets within triplets, but unexpectedly, the feed intake of WCol piglets was lower than that of WCtrl piglets. The daily metabolisable energy (ME) intake level of $\mathrm{W}$ piglets is shown in Figure 1. The daily ME intake level of SR piglets is estimated according to Le Dividich and Sève [8] and varied from $7646 \pm$ $1368 \mathrm{~kJ} \cdot \mathrm{d}^{-1}$ at d 29 to $5355 \pm 1350 \mathrm{~kJ} \cdot \mathrm{d}^{-1}$ at $\mathrm{d} 35$.

\subsection{Slaughter procedure}

Prior to slaughter, all piglets were fasted for $3 \mathrm{~h}$. Two hours before slaughter, the piglets were given intraperitonealy a solution of bromodeoxyuridine (Sigma-Aldrich Chimie, Lyon, France) at the rate of $50 \mathrm{mg} \cdot \mathrm{kg}^{-1}$ BW. Fifteen minutes before slaughter a solution of $\left[{ }^{15} \mathrm{~N}\right]$ valine was given via the jugular catheter in 28d-old piglets for the determination of the fractional protein synthesis rate (FSR). Piglets were killed through intracardiacal injection of an overdose of sodium thiopental $\left(30 \mathrm{mg} \cdot \mathrm{kg}^{-1}\right.$ BW; Nesdonal, Merial, France) and exsanguinated. Fresh gastric contents were immediately collected and the $\mathrm{pH}$ was determined using a pH meter (704 model, Metrohm, France). The entire small intestine (SI) from the pyloric sphincter to the ileocaecal junction was gently removed. The SI was laid on a glass sheet placed on crushed ice. From the first $50 \mathrm{~cm}$ (duodenum), two 2-cm long segments with their contents (1 and $20 \mathrm{~cm}$ from the pyloric sphincter) were removed, weighed, transported in Ringer buffer and stored at $4{ }^{\circ} \mathrm{C}$ until bacteriological analyses. The remaining SI was then flushed with cold isotonic saline, blotted dry and weighed. Thereafter, two duodenal $2-\mathrm{cm}$ long segments were fixed in phosphate-buffered formalin $(10 \%$, $\mathrm{pH}$ 7.6) for $48 \mathrm{~h}$ at $4{ }^{\circ} \mathrm{C}$ and then stored in 


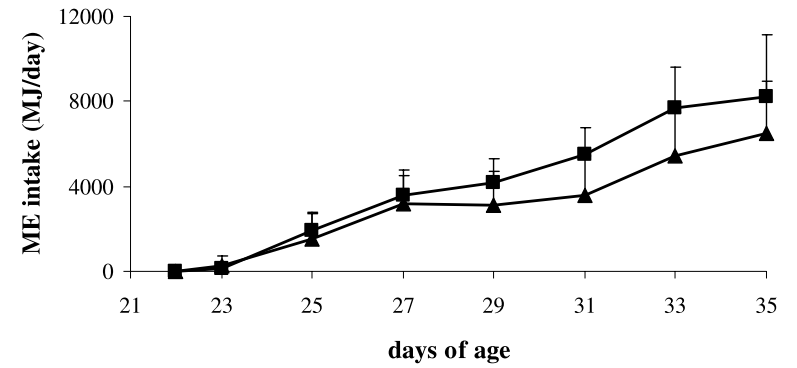

Figure 1. Age related evolution of daily metabolisable energy (ME) intake in weaned piglets fed the control starter diet (WCtrl) or the bovine colostrum-supplemented starter diet (WCol) $(\mathbf{\Delta})$. Values are means \pm SD. ethanol:water $(3 / 1, \mathrm{vol} / \mathrm{vol})$ solution at $4{ }^{\circ} \mathrm{C}$ until structural analyses and paraffin-embedding for immunohistochemistry analyses, whereas the mucosa of a duodenal $30-\mathrm{cm}$ long segment was scraped, frozen in liquid nitrogen and stored at $-80{ }^{\circ} \mathrm{C}$ until protein content, enzyme activity, and bound and free pool $\left[{ }^{15} \mathrm{~N}\right]$ valine analyses. Additionally for the latter analyses, mucosa of a $10-\mathrm{cm}$ long segment of the ileum $(60 \mathrm{~cm}$ before the ileocaecal junction) was scraped, frozen in liquid nitrogen and stored at $-80^{\circ} \mathrm{C}$.

\subsection{Bacteriological analyses}

Duodenal contents of $\mathrm{W}$ piglets were collected in order to evaluate the antibacterial efficacy of the bovine colostrum-supplemented diet. The contents were serially diluted in sterile saline and then cultured on Columbia with horse blood (dilutions $10^{-3}$ to $10^{-6}$ ), McConkey (dilutions $10^{-3}$ to $10^{-6}$ ), and Rogosa (dilutions $10^{-3}$ to $10^{-6}$ ) agar base plates that were incubated at $37^{\circ} \mathrm{C}$ for 48, 24 and $48 \mathrm{~h}$, respectively, for aerobia, coliform and lactobacilli counts. The colony forming units were counted on each plate and for each bacterial type on both duodenal sites as described by Krueger et al. [9]. The values were divided by the mass of duodenal contents collected and expressed on a logarithmic basis $(\log N)$. The ratio of coliforms:aerobes, lactobacilli:aerobes and lactobacilli:coliforms were finally calculated.

\subsection{Structural analyses}

Measurements of villous height and crypt depth were made under blind condi- tions. Samples were micro-dissected under binocular optical. According to the technique of Goodlad et al. [10], villi and crypt sizes were measured as reported [11].

\subsection{Immunohistochemistry on bromodeoxyuridine-labelled cells}

The samples of small intestine were cut longitudinally, dehydrated in ethanol $(70 \%$ and $95 \%$ successively), put in butanol, and embedded in paraffin. Serial, histologic sections of $5 \mu \mathrm{m}$ thickness were stained immunohistochemically using a protocol adapted from the Bromodeoxyuridine Immunohistochemistry System kit (Oncogene, San Diego, USA). Briefly, the sections were maintained in a moist chamber at $37{ }^{\circ} \mathrm{C}$ and digested with a trypsin (concentrate:diluant $1 / 1$; vol/vol) solution, incubated first with an anti-bromodeoxyuridine antibody, and then during 30 min with the diaminobenzidin mixture. The cells were scored as positive if they contained unequivocal brown diaminobenzidin deposit. No quantitative threshold was employed. The measurements on 20 crypts per sample were performed using a light microscope (Eclipse E400, Nikon) and analysed by an image analyser (Lucia software) coupled with the light microscope via a camera (Digital camera DXM1200, Nikon). The proportion of proliferating crypt cells was quantified by counting the number of bromodeoxyuridinelabelled cells and expressed as the percent of the total number of cells per crypt. The migration index was defined as the distance between the cell located in the bottom of the crypt and the labelled cell that had migrated 
the furthest along the crypt-villous axis as described by Wynford-Thomas and Williams [12].

\subsection{Enzyme activity assays}

The protein content in mucosal homogenates, lactase (EC 3.2.1.23), maltase (EC 3.2.1.20), and aminopeptidase N (ApN, EC 3.4.11.2) activities were measured according to Marion et al. [13]. The resulting enzymatic units were expressed as nmol of substrate hydrolysed per min (IU).

\subsection{Fractional protein synthesis rate measurements}

The FSR measurements were performed according to Sève et al. [14]. Briefly, a solution of $\left[{ }^{15} \mathrm{~N}\right]$ valine was prepared by mixing $20 \%$ of $\left[{ }^{15} \mathrm{~N}\right]$ valine $99 \%$ mol percent excess (Tracer Technologies, Sommerville, MA) with $80 \%$ of unlabelled L-valine (Sigma-Aldrich Chimie, Lyon, France) to get $19.8 \mathrm{~mol}$ percent excess final enrichment and by diluting with water to give a final concentration of $0.15 \mathrm{~mol} \cdot \mathrm{L}^{-1}$. This solution was injected at a dose of $1.05 \mathrm{mmol} \cdot \mathrm{kg}^{-1} \mathrm{BW}$. Blood was sampled $7 \mathrm{~min}$ before, and 7 and 14 min after the injection $(\mathrm{t} 0)$ of $\left[{ }^{15} \mathrm{~N}\right]$ valine in order to determine the decrease in plasma $\left[{ }^{15} \mathrm{~N}\right]$ valine enrichment. Free and protein-bound valine enrichments were measured by GC-MS coupling (VG Platform II GC 8000, Fisons Instruments, Altricham, Great Britain) and GC-combustion-isotope ratio MS coupling (Isochrom GC, Fisons Instruments, Altricham, Great Britain), respectively. FSR was expressed in percent per $\mathrm{d}\left(\% \cdot \mathrm{d}^{-1}\right)$. Mucosal protein and RNA concentrations were measured as reported by Sève et al. [14].

\subsection{Hormone assays}

Plasma insulin and IGF-I concentrations were determined in duplicates using validated RIA $[15,16]$. The samples were run in a single assay. Plasma insulin and IGF-I concentrations were measured once a day (at $1000 \mathrm{~h}$ ) at 21, 22, 25, 27 and $34 \mathrm{~d}$ of age.
For insulin, the intra-assay $\mathrm{CV}$ was $2.5 \%$ at $1.6 \mathrm{ng} \cdot \mathrm{mL}^{-1}$, and the average sensitivity of the assay, defined as $90 \%$ of total binding, was $0.114 \mathrm{ng} \cdot \mathrm{mL}^{-1}$. Plasma IGF-I concentrations were determined after an acid-ethanol extraction according to Louveau and Bonneau [16]. The intra-assay CV was $11 \%$ at $48.7 \mathrm{ng} \cdot \mathrm{mL}^{-1}$, and the average sensitivity of the assay, defined as $90 \%$ of total binding, was $0.31 \mathrm{ng} \cdot \mathrm{mL}^{-1}$.

\subsection{Statistical analyses}

Analysis of variance was performed using the GLM procedure of the Statistical Analyses System [17]. For growth, structural, digestive functions, and microbiological parameters the effect of age using the residual variation between triplets as error, and the effect of dietary treatment and age $\times$ dietary treatment interaction were tested. For protein synthesis parameters, the effect of dietary treatment using the residual variation within triplets as error, and the effect of site and site $\times$ dietary treatment interaction were tested. For hormone assays, the effect of dietary treatment using the residual variation within triplets as error, and the effect of age and age $x$ dietary treatment interaction were tested. The regression procedure of the Statistical Analyses System was used to assess relationships between villous height and ME intake level. The effect of dietary treatment on villous height with ME intake level as a covariate was tested according to the GLM procedure. When an effect was significant $(P<0.05)$, adjusted Least Squares Means (lsmeans) were compared ( $t$ test). The values presented are lsmeans \pm SEM. The differences were declared significant at $P<0.05$ and tendencies at $P<0.1$ were noticed.

\section{RESULTS}

\subsection{General}

The mean BW of the 21d-old piglets was $6.3 \pm 0.7 \mathrm{~kg}$. BW was significantly 


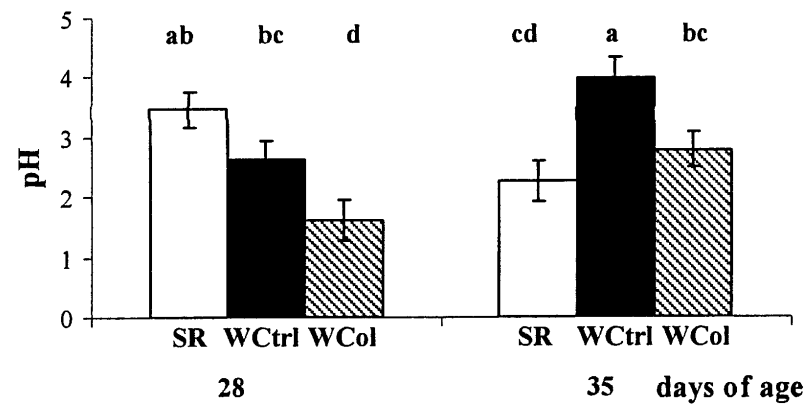

Figure 2. Age related evolution of gastric $\mathrm{pH}$ in sow-reared piglets (SR) (opened bars) and weaned piglets fed the control starter diet (WCtrl) (closed bars) or the bovine colostrum-supplemented starter diet (WCol) (hatched bars). Values are lsmeans \pm SEM. Lsmeans with superscripts without a common letter differ $(P<0.05)$.

Table II. Bacterial counts in the duodenum of weaned piglets fed the control starter diet (WCtrl) or the bovine colostrum-supplemented starter $\operatorname{diet}(\mathrm{WCol})^{1,2}$.

\begin{tabular}{lcccc}
\hline Dietary treatment & WCtrl & WCol & SEM & $P$ value \\
\hline Coliform (log N coliform/log N aerobia) & 0.74 & 0.68 & 0.03 & $P=0.20$ \\
Lactobacilli (log N lactobacilli/log N aerobia) & 0.83 & 0.84 & 0.02 & $P=0.80$ \\
Lactobacilli:coliform ratio & $1.19^{\mathrm{a}}$ & $1.63^{\mathrm{b}}$ & 0.16 & $P=005$ \\
\hline
\end{tabular}

1 Values are lsmeans. Lsmeans without a common superscript within a row $\operatorname{differ}(P<0.05)$.

2 Values of bacterial counts were expressed in $\log$ of counts per g of contents $(\log N)$.

increased with age $(P=0.006)$ and affected by dietary treatment $(P<0.001)$. At $28 \mathrm{~d}$ of age, the BW of SR piglets $(9.4 \pm 0.4 \mathrm{~kg})$ was $36 \%$ and $32 \%$ higher than in WCtrl $(6.9 \pm$ $0.4 \mathrm{~kg})$ and $\mathrm{WCol}(7.1 \pm 0.4 \mathrm{~kg})$ piglets, respectively. At $35 \mathrm{~d}$ of age BW of SR piglets was $10 \%$ and $24 \%$ higher than in WCtrl $(9.9 \pm 0.4 \mathrm{~kg})$ and $\mathrm{WCol}(8.8 \pm 0.4 \mathrm{~kg})$ piglets, respectively. Although both groups of $\mathrm{W}$ piglets were pair-fed, feed intake of WCol piglets was slightly, but non significantly $(P>0.05)$ lower during the second post-weaning week, explaining their lower BW. No diarrhoea was observed during the experimental period. There was no effect of age on any of the parameters studied, except for plasma insulin concentrations. There was no age $\times$ dietary treatment interaction, except for gastric $\mathrm{pH}$ and plasma IGF-I concentrations. Therefore, when age and age $x$ dietary treatment interaction were non sig- nificant, data from the two slaughter ages were pooled.

\subsection{Influence of dietary treatment on gastric pH and duodenal bacterial counts}

A significant age $\times$ dietary treatment interaction $(P=0.002)$ was found for gastric $\mathrm{pH}$. At $28 \mathrm{~d}$ of age, gastric $\mathrm{pH}$ in WCol piglets was the lowest and different $(P<$ $0.05)$ from values in SR and WCtrl piglets that tended to be different $(P=0.07)$ (Fig. 2). At $35 \mathrm{~d}$ of age, gastric $\mathrm{pH}$ similar in both $\mathrm{SR}$ and WCol groups was lower $(P<0.05)$ than that in the WCtrl group. Bacteriological analyses were performed on W piglets only. There was no effect of the dietary treatment on coliform and lactobacilli counts expressed per total aerobia microflora (Tab. II), whereas the lactobacilli:coliform ratio was $37 \%$ higher $(P=0.05)$ in WCol piglets compared to $\mathrm{WCtrl}$ piglets. 
Table III. Duodenal villous height, crypt depth, crypt cell proliferation and migration index in sowreared piglets (SR) and weaned piglets fed the control starter diet (WCtrl) or the bovine colostrumsupplemented starter diet $(\mathrm{WCol})^{1}$.

\begin{tabular}{lccccc}
\hline Dietary treatment & SR & WCtrl & WCol & SEM & $P$ value \\
\hline Mucosal structure & & & & & \\
Villous height $(\mu \mathrm{m})^{2}$ & $521^{\mathrm{a}}$ & $437^{\mathrm{b}}$ & $472^{\mathrm{ab}}$ & 20 & $P<0.01$ \\
Crypt depth $(\mu \mathrm{m})$ & 314 & 323 & 338 & 12 & $P=0.37$ \\
Villous height crypt depth ratio & $1.7^{\mathrm{a}}$ & $1.3^{\mathrm{b}}$ & $1.3^{\mathrm{b}}$ & 0.1 & $P<0.01$ \\
\hline Crypt cell BrdU labelling & & & & & \\
\hline Proliferation $(\%$ SR piglets) & 100 & 116 & 115 & 5 & $P=0.08$ \\
Migration index $(\mu \mathrm{m})$ & 306 & 364 & 387 & 36 & $P=0.31$ \\
\hline
\end{tabular}

1 Values are lsmeans. Lsmeans without a common superscript within a row differ $(P<0.05)$.

2 Adjusted lsmeans according to covariance analyses using ME intake level during the 3 days preceding slaughter as covariate.

3 Two hours before slaughter, a solution of bromodeoxyUridine (BrdU) was intraperitonealy injected $\left(50 \mathrm{mg} \cdot \mathrm{kg}^{-1} \mathrm{BW}\right)$. The proportion of BrdU-labelled crypt cells per total crypt cells was expressed as a percent of the proportion observed in SR piglets (proliferation). The migration index was defined as the distance between the cell located in the bottom crypt and the labelled cell that has migrated the furthest along the crypt-villous axis.

\subsection{Influence of dietary treatment on duodenal structure, crypt cell proliferation and migration index}

The relative SI weight was $10 \%(P=$ $0.15)$ and $18 \%(P<0.05)$ higher in WCtrl $\left(33.5 \pm 1.4 \mathrm{~g} \cdot \mathrm{kg}^{-1} \mathrm{BW}\right)$ and WCol $(35.9 \pm$ $\left.1.4 \mathrm{~g} \cdot \mathrm{kg}^{-1} \mathrm{BW}\right)$ piglets, respectively, than in SR piglets $\left(30.4 \pm 1.5 \mathrm{~g} \cdot \mathrm{kg}^{-1} \mathrm{BW}\right)$. There was no difference between the $\mathrm{W}$ piglets. Since the regression procedure was significant between villous height and ME intake level, the effect of dietary treatment on villous height was tested with ME intake level as a covariate. Villous height was $16 \%$ reduced $(P<0.01)$ in WCtrl piglets compared to SR piglets, whereas the value for WCol piglets was intermediate and did not differ significantly from the values of the other dietary treatments (Tab. III). There was no effect of dietary treatment on crypt depth. The villous height/crypt depth ratio was similar in both $\mathrm{W}$ groups and $24 \%$ lower $(P<0.005)$ than that in SR piglets. Crypt cell proliferation in $\mathrm{W}$ piglets was $15 \%$ higher $(P<0.05)$ than that in SR piglets. There was no dietary treatment effect on migration index.

\subsection{Influence of dietary treatment on enzyme activities and protein synthesis}

There was no effect of dietary treatment on protein contents (average value: $113 \pm$ $1.5 \mathrm{mg} \cdot \mathrm{g}^{-1}$ duodenal mucosa). Duodenal lactase and aminopeptidase $\mathrm{N}$, but not maltase, specific activities (SA) were significantly affected $(P<0.05)$ by the dietary treatment (Tab. IV). Compared to SR piglets, lactase SA was $39 \%$ reduced $(P<0.05)$ in WCtrl piglets. The $29 \%$ reduction $(P=$ 0.08 ) in WCol piglets was intermediate. Aminopeptidase N SA was similar in both $\mathrm{W}$ groups and $24 \%(P<0.05)$ lower than in SR piglets.

Mucosal protein synthesis was determined in the duodenum and ileum on $28 \mathrm{~d}-$ old piglets only. There was no significant site $\times$ dietary treatment interaction $(P=$ $0.17)$. The ribosomal capacity was similar in $\mathrm{W}$ piglets and $21 \%$ higher $(P<0.01)$ than in SR piglets (Tab. V). Dietary treatment tended $(P=0.07)$ to affect FSR that was higher in $\mathrm{W}$ piglets compared to SR piglets. Ribosomal activity was similar across the 
Table IV. Digestive enzyme activities in the duodenum of sow-reared piglets (SR) and weaned piglets fed the control starter diet (WCtrl) or the bovine colostrum-supplemented starter diet (WCol) ${ }^{1}$.

\begin{tabular}{lccccc}
\hline Dietary treatment & SR & WCtrl & WCol & SEM & $P$ value \\
\hline${\text { Lactase (IU } \cdot \mathrm{mg}^{-1} \text { protein) }}^{2}$ & $31^{\mathrm{a}}$ & $19^{\mathrm{b}}$ & $22^{\mathrm{ab}}$ & 3 & $P=0.04$ \\
Maltase (IU $\cdot \mathrm{mg}^{-1}$ protein) & 120 & 120 & 143 & 15 & $P=0.46$ \\
Aminopeptidase (IU $\cdot \mathrm{mg}^{-1}$ protein) & $74^{\mathrm{a}}$ & $58^{\mathrm{b}}$ & $54^{\mathrm{b}}$ & 5 & $P=0.03$ \\
\hline
\end{tabular}

${ }^{1}$ Values are lsmeans. Lsmeans without a common superscript within a row $\operatorname{differ}(P<0.05)$.

2 IU: nmol of substrate hydrolysed per min.

Table V. Duodenal and ileal protein synthesis in 28d-old sow-reared piglets (SR) and weaned piglets fed the control starter diet (WCtrl) or the bovine colostrum-supplemented starter diet $(\mathrm{Col})^{1,2}$.

\begin{tabular}{lcccccccccc}
\hline & \multicolumn{3}{c}{ Dietary treatment } & \multicolumn{7}{c}{ Site } \\
\cline { 2 - 10 } & SR & WCtrl & WCol & SEM & P value & duodenum & ileum & SEM & $P$ value \\
\hline $\begin{array}{l}\text { Ribosomal capacity } \\
\left(\mu \mathrm{g} \text { RNA.mg }{ }^{-1} \text { protein) }\right.\end{array}$ & $36^{\mathrm{a}}$ & $43^{\mathrm{b}}$ & $44^{\mathrm{b}}$ & 1 & $P<0.01$ & $36^{\mathrm{a}}$ & $47^{\mathrm{b}}$ & 2 & $P<0.001$ \\
$\begin{array}{l}\text { Fractional protein } \\
\text { synthesis rate }\left(\% \cdot \mathrm{d}^{-1}\right)\end{array}$ & 99 & 120 & 125 & 8 & $P=0.07$ & 120 & 109 & 7 & $P=0.260$ \\
$\begin{array}{l}\text { Ribosomal activity } \\
(\mathrm{mg} \text { protein/mg RNA/d) }\end{array}$ & 28 & 27 & 29 & 21 & $P=0.67$ & $33^{\mathrm{a}}$ & $23^{\mathrm{b}}$ & 1 & $P<0.001$ \\
\hline
\end{tabular}

${ }^{1}$ Values are lsmeans. Lsmeans without a common superscript within a row (dietary treatment or site) differ $(P<0.05)$.

${ }^{2}$ Fifteen minutes before slaughter, a solution of $\left[{ }^{15} \mathrm{~N}\right]$ valine (19.8 mol percent excess final enrichment and $0.15 \mathrm{~mol} \cdot \mathrm{L}^{-1}$ final concentration) was administered via the jugular catheter in $28 \mathrm{~d}$-old piglets $\left(1.05 \mathrm{mmol} \cdot \mathrm{kg}^{-1} \mathrm{BW}\right)$. Free and protein-bound valine enrichments were measured. Fractional protein synthesis rate was calculated as the ratio of protein bound to protein-free valine enrichments and expressed in percent per d.

dietary treatments. Compared to the duodenum, the ribosomal capacity was $30 \%$ higher $(P<0.001)$ and the ribosomal activity was $30 \%$ lower $(P<0.0005)$ in the ileum. FSR was not significantly different in the duodenum and ileum.

\subsection{Influence of dietary treatment on plasma insulin and IGF-I concentrations}

A significant age $\times$ dietary treatment interaction was found $(P=0.004)$ on plasma IGF-I concentrations (Fig. 3A). Compared to SR piglets, plasma IGF-I concentrations were $70 \%(P<0.01)$ and $63 \%$ $(P<0.05)$ lower in $\mathrm{W}$ piglets on $\mathrm{d} 22$ and 27 respectively, whereas there was no significant effect of dietary treatment on $\mathrm{d} 35$.
There was no effect of dietary treatment and age $\times$ dietary treatment interaction on plasma insulin concentrations, but a significant effect of age was found $(P<0.001)$ (Fig. 3B). Compared to $\mathrm{d} 21$, the plasma insulin concentration was increased by $200 \%(P<0.001)$ at $\mathrm{d} 25$ and remained unchanged thereafter.

\section{DISCUSSION}

Weaning-induced modifications of structure, digestive functions and microflora of the gut are well-described in piglets [1822]. In the present study, the variations of these parameters in $\mathrm{W}$ piglets compared to SR piglets were largely in agreement with the literature data. Following the short acute 

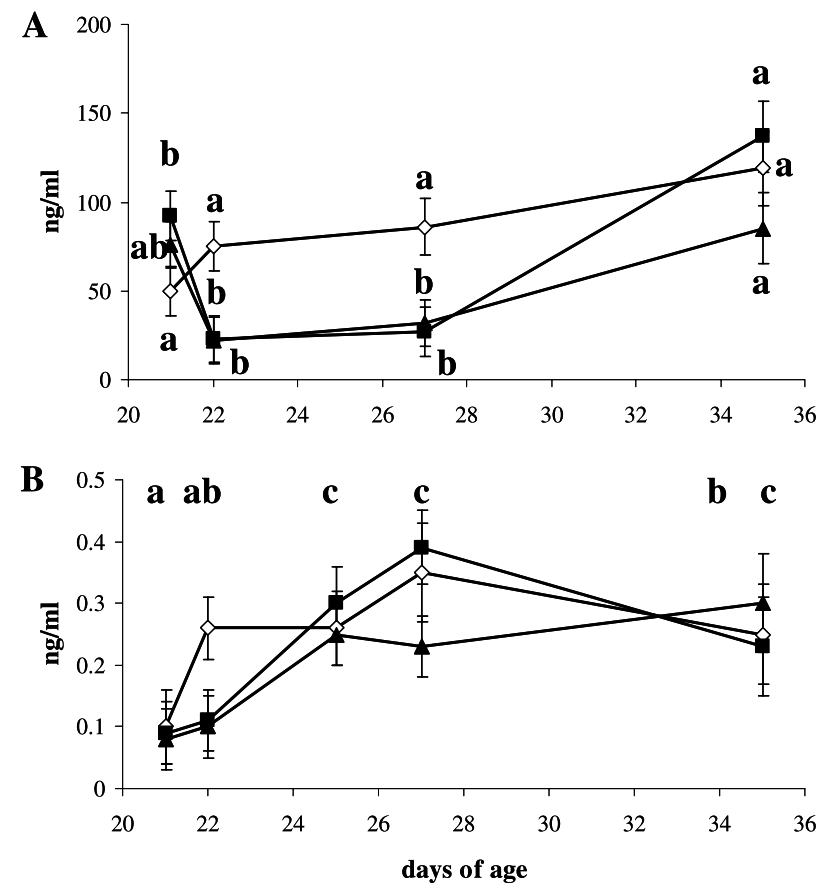

Figure 3. Age related evolution of plasma IGF-I (A) and insulin (B) concentrations in sow-reared piglets $(\mathrm{SR})(\diamond)$ and weaned piglets fed the control starter diet (WCtrl) $(\boldsymbol{\square})$ or the bovine colostrumsupplemented starter diet (WCol) $(\boldsymbol{\Delta})$. Values are lsmeans \pm SEM. For IGF-I (significant age $\times$ dietary treatment interaction) lsmeans with superscripts without a common letter differ $(P<0.05)$. Insulin superscripts without a common letter indicate a significant age effect $(P<0.05)$.

phase observed during the first $3-5$ postweaning days, the adaptive phase corresponding to the progressive restoration and maturation of the gut and its microflora lasts up to two weeks [20, 23-25]. In the present study, W piglets were slaughtered during this adaptive phase. The similar treatmentinduced effects measured at both ages suggest that observed effects of the colostrum-supplemented diet were maintained throughout this adaptive phase. Therefore the discussion concentrates on the effects of the added freeze-dried colostrum in the weaning diet.

The colostrum-supplemented diet significantly improved the lactobacilli:coliform ratio in $\mathrm{W}$ piglets. This effect was mainly caused by numerically lower coliform counts whereas lactobacilli counts were identical between WCtrl and WCol piglets. Lower gastric $\mathrm{pH}$ in $\mathrm{WCol}$ piglets strengthened the effects of colostral antibacterial components. The coliform population, which may concern some pathogenic strains usually considered as harmful for gut health, was shown to be less resistant to low $\mathrm{pH}$ than the lactobacilli population [26]. The relationship between gastric $\mathrm{pH}$ and colostrum supplementation remains nevertheless to be explained. A successful use of colostrum in the treatment of diarrhoea caused by enteropathogenic Escherichia coli, a member of the coliform-type microflora, has already been reported in human patients [27-29]. Colostrum contains a large number of antimicrobial components, including lactoferrin, lysozyme, lactoperoxidase which have been shown to inhibit the growth of several pathogenic bacteria. In addition bovine colostral 
immunoglobulins may provide local protection within the gut as described in newborn piglets [30] and may stimulate the SI immune system [5].

The effect of colostrum supplementation was studied within groups of weaned piglets. Moreover, sow-reared piglets were considered as a reference of undisturbed animals considering digestive functions. Therefore suckling piglets were compared with weaned piglets fed a colostrum-supplemented diet in order to evaluate colostrum-induced improvement of weaning transition from digestive physiological aspects. Adding colostrum in the starter diet of weaned piglets resulted in numerically higher SI relative weight and duodenal villous height, indicating that colostrum may stimulate mucosa growth as it has already been demonstrated in rodents [3]. Authors have also described a colostrum-induced enhancement of cell proliferation and migration using in vitro human colonic carcinoma cells and rat SI epithelial cell models of wound repair [3]. Our results in vivo did not confirm these latter observations since any significant variation in crypt cell proliferation and migration was explained by the colostrum treatment. The amount of colostrum reaching the epithelial barrier of the SI in vivo was probably lower than that applied to cells in vitro. Moreover it is well known that weaning-induced crypt cell proliferation is plateauing as early as the third day post-weaning $[22,31]$. The possibility that the colostrum-supplemented diet stimulated cell proliferation during the first 3 post-weaning days cannot be excluded.

Weaning-induced changes in the phenotype of enterocytes correspond to the maturation of digestive functions in response to the change from maternal milk to a weaning diet. In agreement with reported data [3234], this period is characterised by a decrease in lactase and peptidase specific activities and an increase in maltase specific activity. An additional effect of the colostrum-supplemented diet was not observed, although values of disaccharidases were numerically higher in colostrum-fed piglets. To our knowledge, no previous study documented the effect of colostrum on SI enzyme activities in $\mathrm{W}$ piglets.

In agreement with the data of Sève et al. [35], the ribosomal capacity was enhanced by weaning. The addition of colostrum in the weaning diet did not increase FSR. In contrast, in early weaned piglets fed a starter diet supplemented with a bovine colostral fraction high in growth factors for 5 days, duodenal FSR was significantly increased by $20 \%$ [36]. The lower amount of growth factors provided by the colostrum in the present study compared to a study of Marion et al. (illustrated by a 4-fold lower amount of colostral IGF-I intake the day before slaughter and no variation in plasma IGF-I levels) could explain the observed discrepancy in the intestinal mucosa response. Hence, a minimal provision of both nutrients and growth factors must be achieved at the epithelial barrier surface to induce change in FSR. The decrease in the ribosomal activity from the proximal to distal SI may be related to the progressively lower input of nutrients toward the distal intestine. In artificially fed neonatal piglets, FSR was twice as high in the jejunum as in the ileum [37].

In conclusion, a diet supplemented with colostrum induced, although not always significantly, variations of gut parameters, suggesting that globally colostrum may limit weaning-induced gut structural and microbial alterations. The present data also suggest that the observed effects of colostrum occurred early and were maintained throughout the first two weeks following weaning, corresponding to the post-weaning adaptive phase. The identification of molecules accounting for these effects will require further investigations.

\section{ACKNOWLEDGEMENTS}

The authors thank Christelle David, Philippe Ganier, Jean-Noël Thibault, Françoise Thomas, Anne Pasquier and Cécile Perrier for their valuable technical assistance. 


\section{REFERENCES}

[1] Le Huërou-Luron I, Huguet A, Callarec J, Leroux T, Le Dividich J. Supplementation of a weaning diet with bovine colostrum increases feed intake and growth of weaned piglets. In: ITP (Ed), 36e J Rech Porcine, Paris, France, 2004, p 33-38.

[2] Pluske JR, Pearson G, Morel PCH, King MR, Skilton G, Skilton R. A bovine colostrum product in a weaner diet increases growth and reduces days to slaughter. In: Cranwell PD (Ed), Australasian Pig Science Association Publication. VIIth Manipulating Pig Production, Adelaide, Australia, 1999, p 256.

[3] Playford RJ, Floyd DN, MacDonald CE, Calnan DP, Adenekan RO, Johnson W, Goodlad RA, Marchbank T. Bovine colostrum is a health food supplement which prevents NSAID induced gut damage. Gut 1999 , 44: 653-658.

[4] Khan Z, Macdonald C, Wicks AC, Holt MP, Floyd D, Ghosh S, Wright NA, Playford RJ. Use of the "nutriceutical", bovine colostrum, for the treatment of distal colitis: results from an initial study. Aliment Pharmacol Ther 2002, 16: 1917-1922.

[5] Solomons NW. Modulation of the immune system and the response against pathogens with bovine colostrum concentrates. Eur $\mathbf{J}$ Clin Nutr 2002, 56 Suppl 3: S24-S28.

[6] Pakkanen R, Aalto J. Review Paper: Growth factors and antimicrobial factors in bovine colostrum. Int Dairy J 1997, 7: 285-297.

[7] Sève B. Alimentation du porc en croissance : intégration des concepts de protéine idéale, de disponibilité digestive des acides aminés et d'énergie nette. INRA Production animale Paris, 1994, 7: 275-291.

[8] Le Dividich J, Sève B. Effects of underfeeding during the weaning period on growth, metabolism, and hormonal adjustments in the piglet. Domest Anim Endocrinol 2000, 19: 63-74.

[9] Krueger M, Schroedl W, Isik W, Lange W, Hagemann L. Effects of lactulose on the intestinal microflora of periparturient sows and their piglets. Eur J Nutr 2002, 41: 26-31.

[10] Goodlad RA, Levi S, Lee CY, Mandir N, Hodgson H, Wright NA. Morphometry and cell proliferation in endoscopic biopsies: evaluation of a technique. Gastroenterology 1991, 101: 1235-1241.

[11] Marion J, Biernat M, Thomas F, Savary G, Le Breton Y, Zabielski R, Le Huërou-Luron I, Le Dividich J. Small intestine growth and mor- phometry in piglets weaned at 7 days of age. Effects of level of energy intake. Reprod Nutr Dev 2002, 42: 339-354.

[12] Wynford-Thomas D, Williams ED. Use of bromodeoxyuridine for cell kinetic studies in intact animals. Cell Tissue Kinet 1986, 19: 179-182.

[13] Marion J, Petersen Y, Rome V, Thomas F, Sangild PT, Le Dividich J, Le Huërou-Luron I. Early weaning stimulates intestinal brush border enzyme activities in piglets, mainly at the postranscriptional level. J Pediatr Gastroenterol Nutr 2005, 41: 401-410.

[14] Seve B, Ballevre O, Ganier P, Noblet J, Prugnaud J, Obled C. Recombinant porcine somatotropin and dietary protein enhance protein synthesis in growing pigs. J Nutr 1993, 123: 529-540.

[15] Prunier A, Martin C, Mounier AM, Bonneau $\mathrm{M}$. Metabolic and endocrine changes associated with undernutrition in the peripubertal gilt. J Anim Sci 1993, 71: 1887-1894.

[16] Louveau I, Bonneau M. Effect of a growth hormone infusion on plasma insulin-like growth factor-I in Meishan and large white pigs. Reprod Nutr Dev 1996, 36: 301-310.

[17] SAS Institut Inc., SAS/STAT User's Guide: Statistic, Version 6 ed. SAS Institut, Cary, NC, 1989.

[18] Hampson DJ. Alterations in piglet small intestinal structure at weaning. Res Vet Sci 1986, 40: $32-40$.

[19] Cera KR, Mahan DC, Cross RF, Reinhart GA, Whitmoyer RE. Effect of age, weaning and postweaning diet on small intestinal growth and jejunal morphology in young swine. $\mathrm{J}$ Anim Sci 1988, 66: 574-584.

[20] Pluske JR, Hampson DJ, Williams IH. Factors influencing the structure and function of the small intestine in the weaned pig: a review. Livestock Prod Sci 1997, 51: 215-236.

[21] Jensen B. The impact of feed additives on the microbial ecology of the gut in young pigs. $\mathrm{J}$ Anim Feed Sci 1998, 7: 45-64.

[22] Hedemann MS, Hojsgaard S, Jensen BB. Small intestinal morphology and activity of intestinal peptidases in piglets around weaning. J Anim Physiol Anim Nutr 2003, 87: $32-41$.

[23] Bach Knudsen K E, Jorgensen H. Intestinal degradation of dietary carbohydrates-from birth to maturity. In: Ball RO (Ed), The 9th International Symposium on Digestive Physiology in Pigs, Banff, Alberta, Canada, 2003, p $110-120$. 
[24] Risley CR, Kornegay ET, Lindemann MD, Wood CM, Eigel WN. Effect of feeding organic acids on selected intestinal content measurements at varying times postweaning in pigs. J Anim Sci 1992, 70: 196-206.

[25] Burrin DG, Stoll B. Enhancing intestinal function to improve growth and efficiency. In: Ball RO (Ed), Proc 9th Digestive Physiology in Pigs, Banff, Alberta, Canada, 2003, p 121137.

[26] Franco LD, Fondevila M, Lobera MB, Castrillo C. Effect of combinations of organic acids in weaned pig diets on microbial species of digestive tract contents and their response on digestibility. J Anim Physiol Anim Nutr 2005, 89: 88-93.

[27] Saha K, Dua N, Chopra K. Use of human colostrum in the management of chronic infantile diarrhoea due to enteropathogenic E. coli infection with associated intestinal parasite infestations and undernutrition. J Trop Pediatr 1990, 36: 247-250.

[28] Carbonare SB, Silva ML, Palmeira P, Carneiro-Sampaio MM. Human colostrum $\operatorname{Ig} \mathrm{A}$ antibodies reacting to enteropathogenic Escherichia coli antigens and their persistence in the faeces of a breastfed infant. J Diarrhoeal Dis Res 1997, 15: 53-58.

[29] Honorio-Franca AC, Carvalho MP, Isaac L, Trabulsi LR, Carneiro-Sampaio MM. Colostral mononuclear phagocytes are able to kill enteropathogenic Escherichia coli opsonized with colostral IgA. Scand J Immunol 1997, 46: 59-66.

[30] White KR, Anderson DM, Bate LA. Increasing piglet survavil through an improved farrowing management protocol. Can J Anim Sci 1996, 76: 491-495.
[31] Jiang R, Chang X, Stoll B, Fan MZ, Arthington J, Weaver E, Campbell J, Burrin DG. Dietary plasma protein reduces small intestinal growth and lamina propria cell density in early weaned pigs. J Nutr 2000, 130: 21-26.

[32] Hampson DJ. Attempts to modify changes in the piglet small intestine after weaning. Res Vet Sci 1986, 40: 313-317.

[33] Kelly D, Smyth JA, McCracken KJ. Digestive development of the early-weaned pig. 1. Effect of continuous nutrient supply on the development of the digestive tract and on changes in digestive enzyme activity during the first week post-weaning. Br J Nutr 1991, 65: $169-180$

[34] Le Huërou-Luron I, Peiniau J, Guilloteau P Aumaitre A. Are the activities of intestinal peptidases age- and diet-dependent in piglets? In: Lindberg JE Ogle B (Ed), The 8th International Symposium on Digestive Physiologiy in Pigs, Uppsala, Sweden, 2000, p 20-22.

[35] Sève B, Lebreton Y, Peiniau J, Ganier P. Protein synthesis as influenced by weaning in the young pig. In: Leman J (Ed), The 39th International congress of the European Association for Animal Production, Rostock, Germany, 1987, p 48-50.

[36] Marion J, Bebin K, Thomas F, Piot M, Fauquant J, Louveau I, Ganier P, Thibault JN, Maubois JL, Sève B, Le Huërou-Luron I, Le Dividich J. Supplementation of a weaning diet with bovine colostrum extract increased villi heights in the duodenum of weaned piglets. In: ITP (Ed), 34e J Rech Porcine, Paris, France, 2002, p 103-108.

[37] Stoll B, Chang X, Fan MZ, Reeds PJ, Burrin DG. Enteral nutrient intake level determines intestinal protein synthesis and accretion rates in neonatal pigs. Am J Physiol Gastrointest Liver Physiol 2000, 279: G288-G294. 